\title{
護謨中に於けるプルシアン・ブリュー及び其他 のフエロシアン化物の作用に就いて注意
}

理學博士 ヂエー・アール スコ・トト

\section{第 一 章 (承前)}

\section{（C）溶劑に對する作用の有樣}

此の事は、また委しく試驗したのではないが二三の亨に就いて速べやう。一般に知られて居る如く 唕練したゴム或はゴムと硫黃からなる配合物っさ゚ンゼンに浸して振滥せずに放置すると直きに粘性

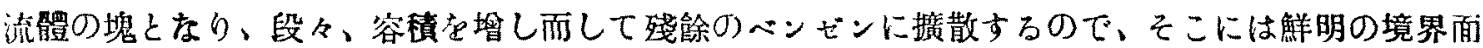
がなくなる。

比較的粗であも鉛及び亞鉛の,エロシアン化物を含有する配合ゴムは同㥞に作用をする。併し乍ら 微細に分散した物質（プルシアン及びターンブルス、ブリュー、ガスブラック）在含有する配合ゴ ムは大いに瞦脹するが完全に鮮明の境界面を示して居て流體にならない、而して二、三日經過しな いミ溶解し始めないのである。且、膨辰は初め讯速で、後は非常に掘くある（第二圆曲線、を見よ）

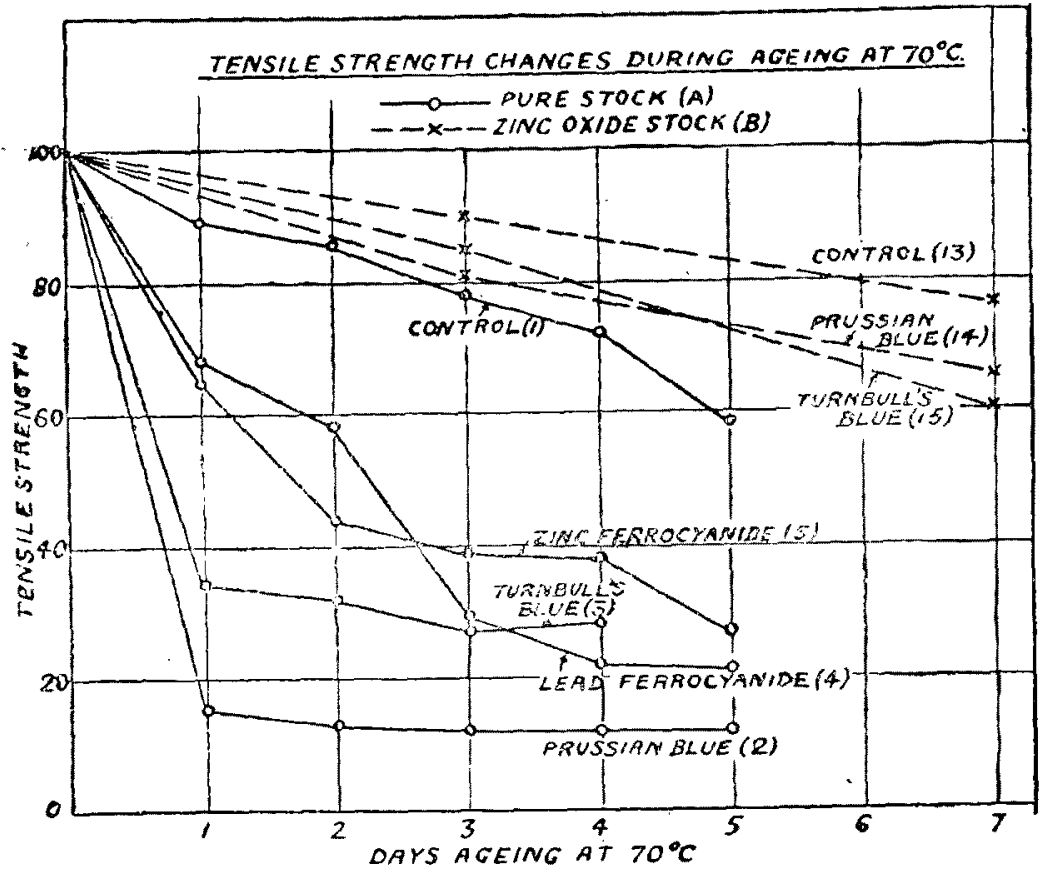


然乃に前者に於ては膨脹は一首殆んぎ平均になつて居る（曲線b）

其れ等の溶劑に對する作用狀態の中、微細に分散した物質を含有する配合ゴムは僅か加硫したゴ ムに類似して居る、而してその事は既に前研究者が發表したところである（例へは、Twiss. J. Soc. Chem. Iud., 1925, 44, 106T, ; Stamberger. Rec. Trav. Chim., 1928, 47, 316)。微細な物貿を含む

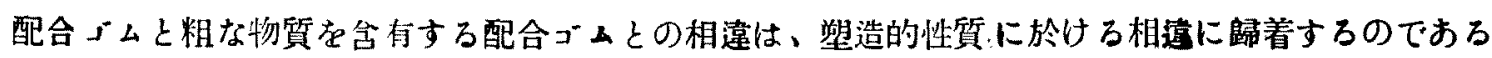

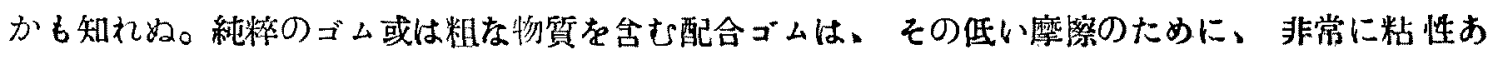
ろ液體の如く實際或る範園の内力の上に德くのでおるといふ事が容易に解る。それ故に、それを他 の溶液に泿漬する時、各溶液は他の溶液に擴散し、そこには鮮明の境界面がない。然るに同じ保件

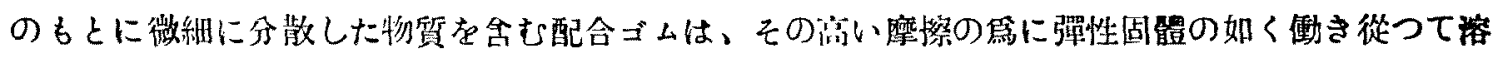
液中に通過せずにゲルに膨非する。

亦最初の膨脹する割合は、この關倸はまを委しく試驗されたのではないけれぎ、摩擦が高い程

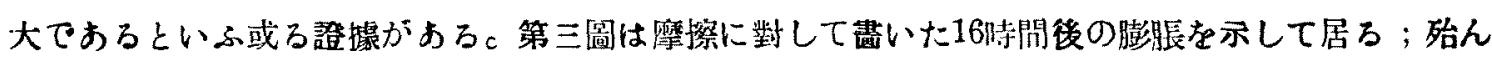
ぞ沂似的の直線關係が明らかに示される。洔問の經過が淮む侍、異ふ配合ゴムの膨脤が第二圖（第 二圖の時問を示す軸の長さは約 150 時䦥を表示する)に於て示される如く、等しくなる傾向をしつ て居ろ。

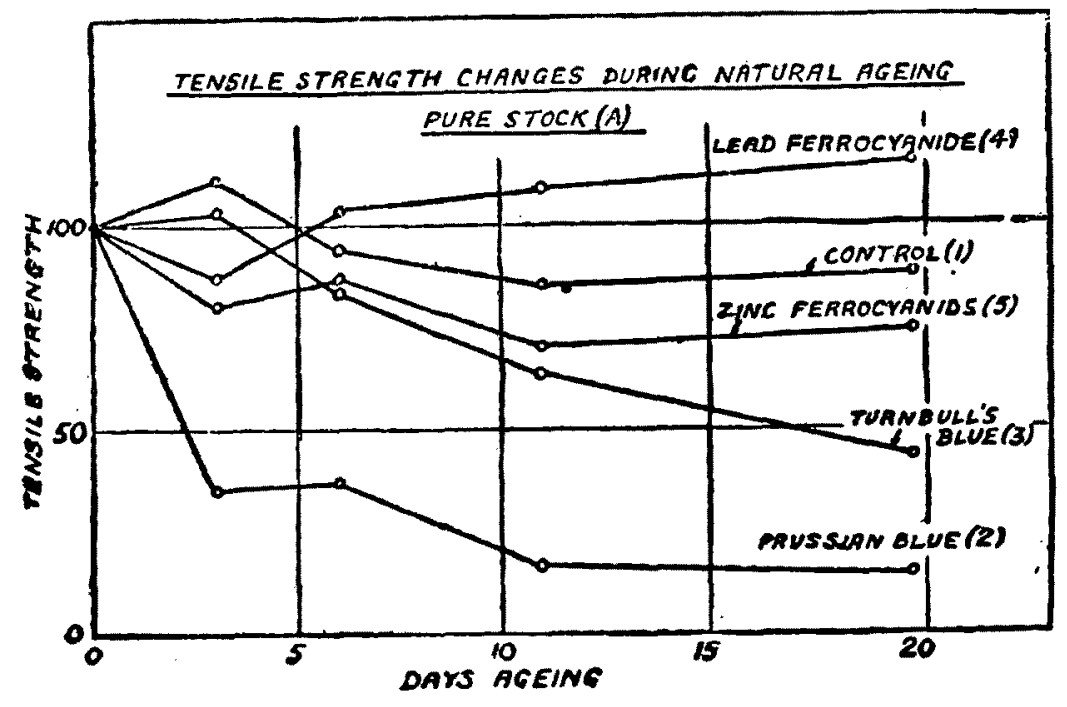

(p) 老化に就いて

ゴムとプルシアン、フリューの配合物は、詝藏して置くと采らかく粘着性になり最後に樹脂狀の ものになる事を見出した。

この事はブルシナン、ブリーが誘導した酸化を暗示するので前进の十ニの未加碚配合ゴムの試料 


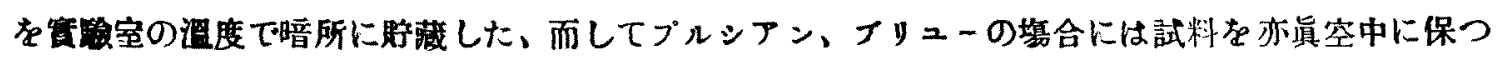
た、そして追加の配合物は酸化防止劑としてキノール（21/2バー七ント）を含んで居る。是等の菑驗 は、ブルシフン、フリュー及びターンプルス、フリューは速かに粘性を惹起し終に樹脂質となすが

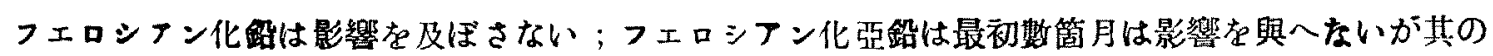
後粘性が繶いて起るこいふ事を示した。何れの易合も粘性は、真空中に詝藏する事或は配合物に硫 黄戏はキールを潦加して、殆んご完全に防ぐ事が出來た。

是等の漞察は、迅速な酸化が起つて居るとの疑念を强めたから配合ゴムのシート(厚さ約一粍)存 空氣中に曝露して定時に其の重量を測つた（第四圖を見よ）。

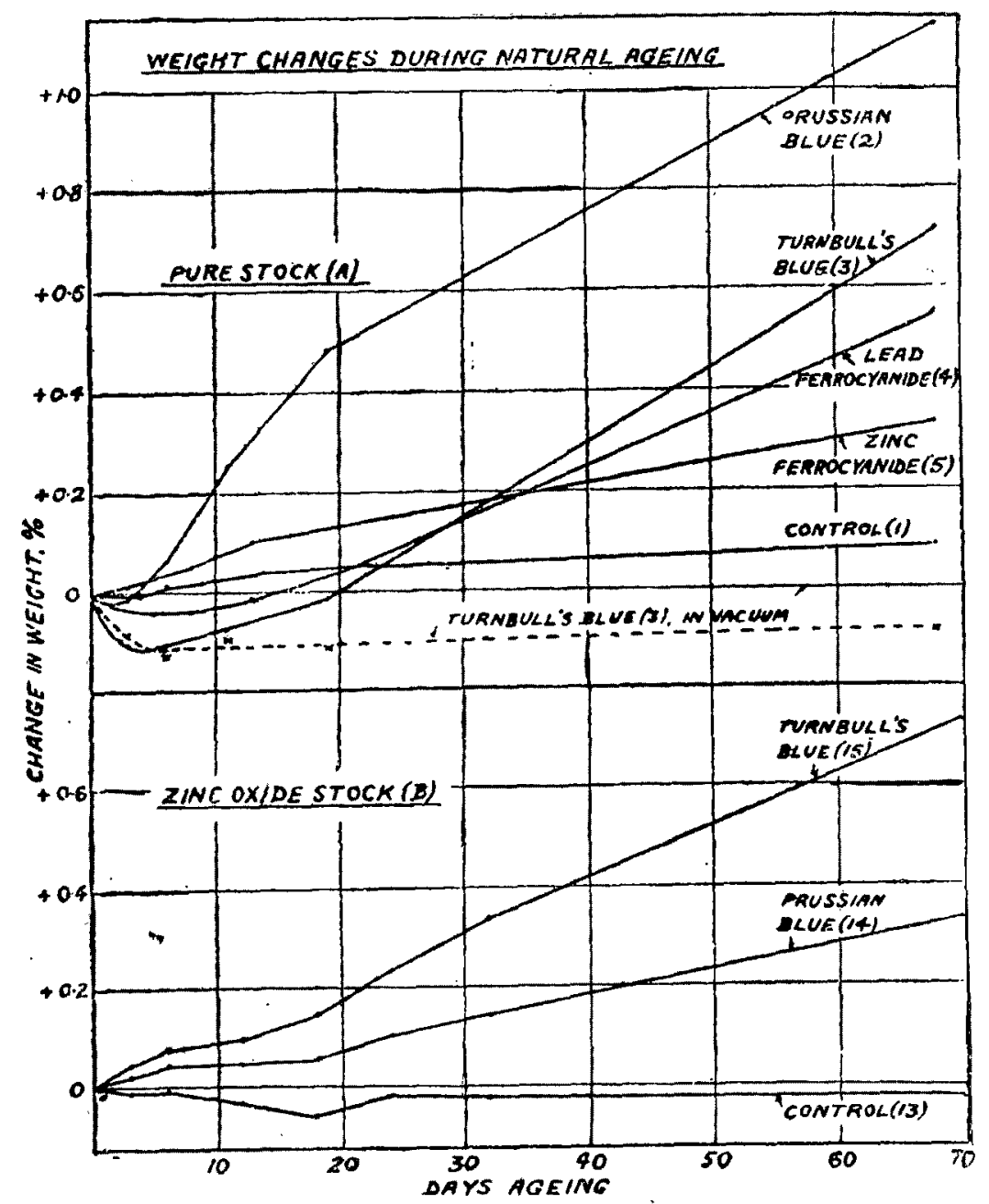

是等の結果は明らかに前の觀察を確䜅した、而して次に示す結論を誘引した

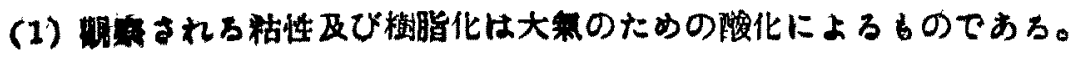


（2）ブルシアン、ブリュー及びターンブルス、フリューは最初から此の变化促進する、而して

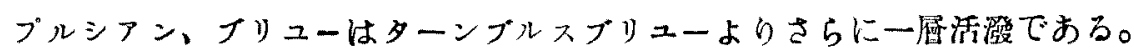

（3）フエロシアン化亞鉛は酸化を促進する、然しをれはかなりの、誘導期”の經過後に作用をす ろ。

（4）フエロシアン化鉛は、加硫ゴムの老化（第三章を見よ）に及性す其の影響つ見地に於ては酸

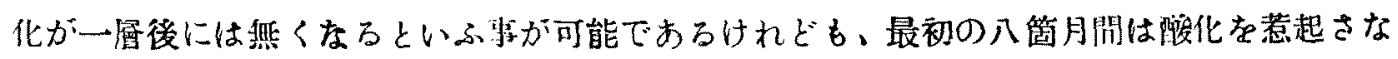
Wo

(5)ブルシアン、プリュー、ターンブルス、プリュー及びフェロシアン化亞鉛に依つて誘導され ろ酸化は、硫频を加ふることに依つて除去はされないが大いに减退する。

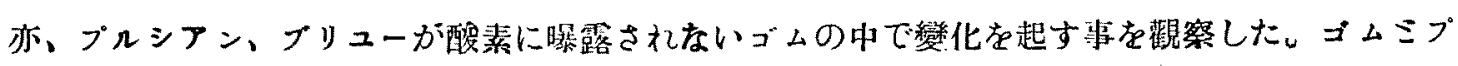

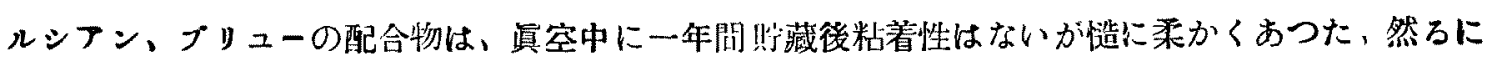

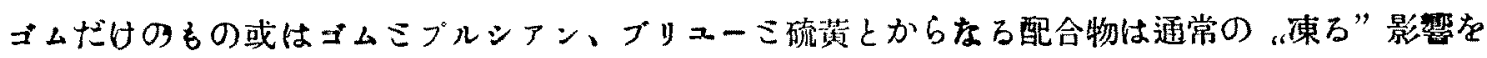
示し全く硬くなつた。

此の事はゴムの中に溶解する或は入り込んで居る酸素の存在に越因するかも知れない。叉はプルシ アン、ブリニードけがゴムの解重合或估分子の解集合を起し、而して硫黃が此の作用在阻止するの であらう、而して此の程合には、バ、ロザン (Rubber Industry, London, 1914, P.149; Delft Communications, 1917 part IV, P. 111)に依ると解重合は常に酸化に先だつて起るのであるから 解重合は恐らく訟化の直接原因であらう。

或乃ゴムに可溶性の鐵化合物は酸化を早めるから、プルシフン、゙リューと樹脂酸との可溶性反 鷹生成物がブリューに低つて起る酸化の原因であるやうに見へる、然し未加硫ブルシフン、プリュ 一の配合ゴムのアセトン抽出物中に、鐵化合物が見出されないから此の解釋はよくない樣に考へら れる。

さらにブルシアン、ブリューは或る物質例八ばアクラルデヒドのオートクシデーション (Moureu, Dufraisse and Badoche, Comptes Rend., 1926, 183, 685) 存促進するものであるこ知られて居ろ。 それ故にヌ゙ルシフン、ブリニー及びターンブルス、ブリューが生ゴムに及ぼす作用は、その作用の

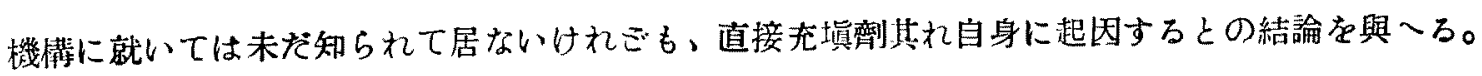

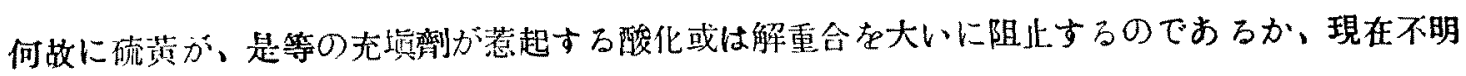

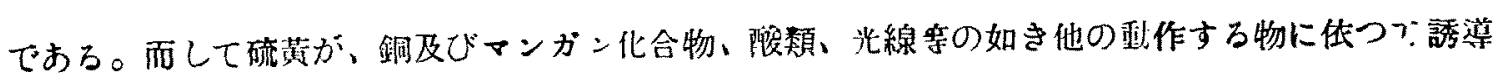
される酸化及び解重合に同様の影響を及ぼすか否やを知る事は興味のおることである。併し作ら硫 
黄がベンッアルデヒドのオートクシデーションを减退する事が知られて扂る（Moureu and Dufrai-

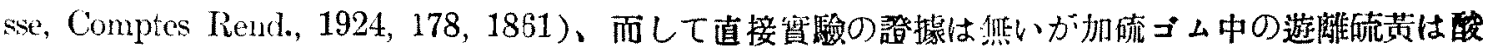
素の作用を减退するこいふ事（Duqué, Rev，Géu. Chut., 1928, Mar. - Apr., P.3) が提言されて居る

\section{第二晏 顏料プルシアン、フリューとターンフルス、フリュー}

\section{（a）末加硫配合コムに就いて}

是等のブリニーとゴムの混合物は、ベールクレーフの場合に於てすら、反射光線の疍に青い色を示 さず却つて黑色に見えるこ、に二つの可能性ある說明在提言する。

（1）其のブリニーは、混合中に分解して黑色の化合物を生成するのであろ。

（2）其のフッューは、ゴムと同じ屈折率をもつので光線がゴムと䔛籼の間から反射しないのでお ろ。

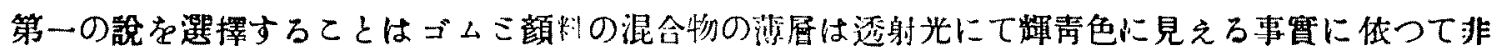
であろ。

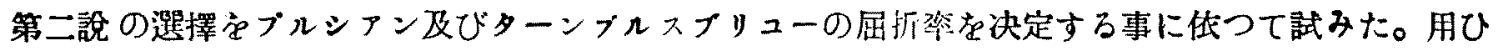
た力法は、一つの固體を與へられた波長の光線に對して同し屆折茶をもつ液體中に浸漬するならば 其の波長の光線は固體と液體の問から反射しないといふ事實に依つて居る。

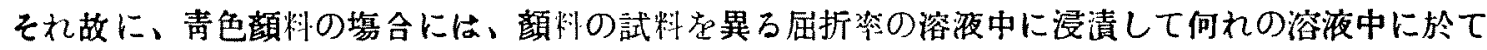
顏判が青色の光線を反射せないか、郎ら反射光線に依つで見える時、黑色か或は青色の餘色（即ち 褐色）の何れか在表はすか觀察するのが唯一の必要な事である。斯くの如き整合は頝籼の屈折率は

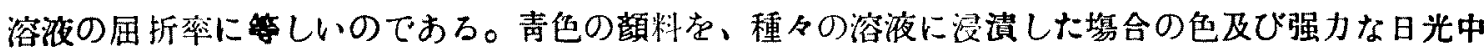
て觀察した色が第三表に與へられて居る。

\begin{tabular}{|c|c|c|c|}
\hline & 䒩 & $\equiv$ & \\
\hline 溶 液 & 屈折 杽 & プルシアン & ターンプルス \\
\hline & ( $\mathrm{F}$ 線) & フリュー & プリニー \\
\hline 水 & 1.337 & 靑、董荣色 & - \\
\hline クロロフォルム & 1.453 & 淡紅、柴色 & 色淡紅，紫色 \\
\hline ベンゼン & 1.513 & 暗赤、褐色 & 晤淡紅ノ褐色 \\
\hline ベンゼン+CS & 1.570 & 暗黄、襡色 & 猎黃ノ褔色(綉色キモッ) \\
\hline ベンゼン+C心 & 1.605 & 暗䌦、褐色 & - \\
\hline
\end{tabular}


以上の結果から推定される屈折卒は次の如くであろ。

$$
\begin{aligned}
& \text { ブルシフン、フリュー…...................... } \\
& \text { ターンプル、プ y ュ }
\end{aligned}
$$

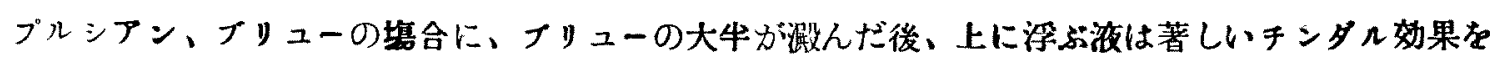
呈した。此の効果の强度は溶液と潘游してるる固體が等しい屈折率をもつ時最少であろから、此の

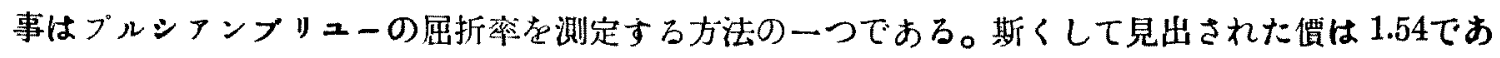
つて他の方法に依つて與へられて價と可なら一致して居る。

プルシフン及びターンブルス、ブリューの毒色光線に對する届折率は生ゴムの届折率（1.54）上 殆んミ゙同じである、而して此の事が明かにゴム中に於ける是等の二つのブリニーに依つて示された 顏料の効力缺乏を說明して居る。

届折率が同一である矛に、プルシアン及びターンプルス、プリューは其の非常に純良の粒子の㙁 合は、實祭の目的に對して、不透明な頌料としてょりも寗ろごムに溶解する染料の如くに作用する 此の事は、ゴムとプルシナン、ブリューの泥合の薄居は青硝子の樣に全く明かな透明のものである 事卧に依つて示される。以上の事柄は、其れ等の使朋に件隨するところの三三の因難な事（例人ば 加硫中に色の消える事や惡い老化性在もつ事等）を除くことが出來るならば透明なゴム製品に、是 等のブリューを使朋する事が出來ると云ふ事暗示して居ら。且つ不透明な青色ゴムる望むならば 白色の頝料を添加の必要であ万事を示して居る。

フェロシアン化亞鉛も亦餘り顔料の効力を示さない、上迌の方法（第三表）に化るこ其の届折率 は1.59であつて此れはゴムの屈折率に非常に接近して居る。

上述の屈折率测定に適用した光學上の原理は、ゴムに使用の物質の顊料効力を語驗する簡單な力法

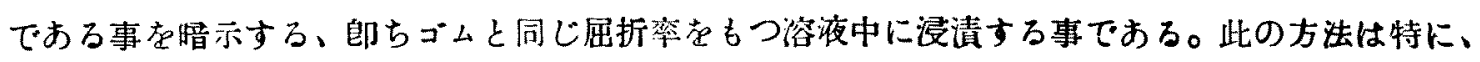

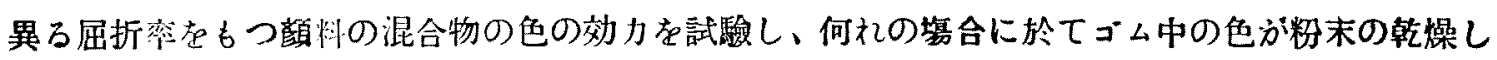
た混合物の色と異るかを知るに有朋であらう。

\section{（b）加硫コムに就いて}

ブルシアン及びターンプルス、フリニーの加硫中及び加硫挠に於けろ作用を次に示す二つの型の四 合に就いて試駸した。

A. 純ゴム 配合第 2 號 ゴム95: 硫黃 5 ; ブルシアン、フリスー 12

配合第 3 號 ヨ゙ム95 硫黄 5 ターンフルス、プッニー 12

（是等は既に第一章中に垥迅せられた配合である） 
B. 由 色 ゴム

配合第13號、ゴム 100 亞鉛華 100 チタニウムホワイト 30 硫带 3.5 D. P. G. 0.5

配合第14號、配合第13躆にプルシアン、ブリュー 15 を加ふ

配合第15號、配合第13踋にターンフルス、ブリュー 15 を加ふ

純ゴム(A) ブルシアン及びターンブルス、ブリューは何れも加硫中(攝氏 153 展に於て) その色が 消える。加硫したてのブルシフン、ブリニー配合物は透射光にて見る時、綠色㾟呈して扂るがター ンブルス、ブリュー配合物は加硫の進むに從つて綠色から褐色に變つて行く。

ブルンアン及びターンブルス、ブリューは熱せられると分解してシアン化水素瞈を發生し青色を失 ふのである、而して二三の還元劑に依つて亦脫色するここが出來る(Thorpe, Dictionary of Applied Chemistry, article “Cyanides”)ミいふ事が知られてて居る。それ故に加硫中色の消失が全く熱

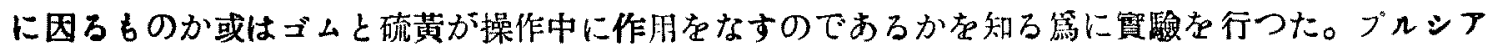
ン及びターンブルス、ブリューの試料を何れも別々に攝氏 150 度に熱し、ゴムに混合し、亦コムと 硫黃(95:5) の配合物に混合した。雅生する瓦斯を總て水酸化晢達溶液中に通じた、而してシテン化

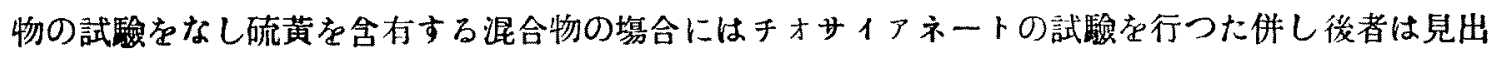

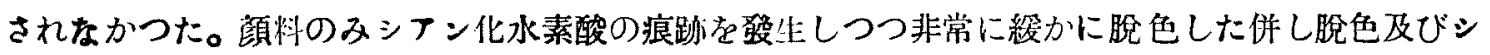
フン化水素酸の發生は共に、ゴムを䔛料に混合することに依つて促進され而して 向一首ゴムこ硫黄 を混合することに侬つて促進された：ア七トン抽出に低つてゴムから橲の除去されるここが减少 したけれご是等の力法に於けろ促進効力は除去されなかつた。何れの程合もターンブルス、ブリン 一はブルシフン、ブリューより一層速かに脘色し且つ多くのシアン化水素酸を發生した。それ故に 是等のゴム配合物に於て色の消えろ事はシアン化水素酸の發生ミ澡い關倸があり而してゴム、ゴム 樹脂及び硫黄は皆是等の操作を促進する作用をなす事が明暸である。

併し乍ら加硫中青色が消失することは完全な不可逆のものでは無い、といふのは空氣に懪露する と一部分か或は完全に色が回復されるからである。色の回復は空氣の存在せぬ昜合は起らない、そ

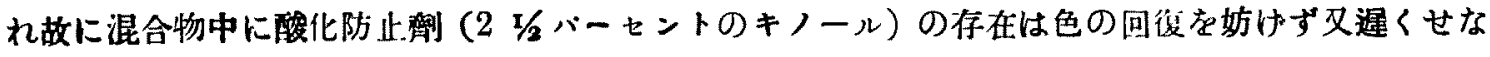
い事が知られて居るけれども、色の回復は酸化によろに相違ない。色の回復はうごムの加硫時間の長 い程、紱やかであろ。

ブルシフンフリュー及びターンプルス、ブリュー配合物は色の回復する過程が大いに相違する ブルシフン、ブリューでは数分間空氣に曝露するミ外側が濃い青色になり、厚さ 0.5 粍の首はー日

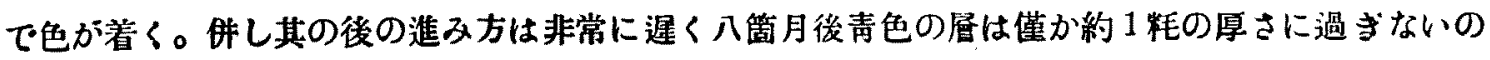




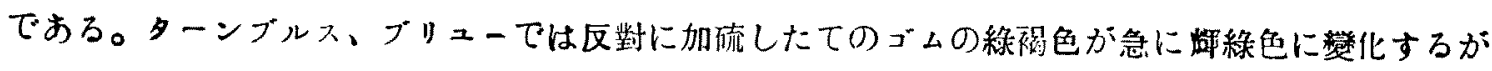

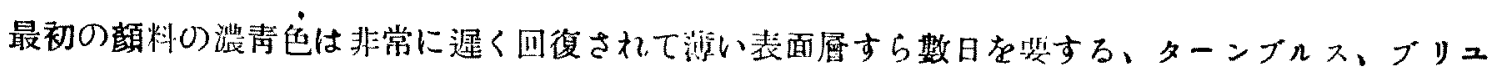
一では青色と不變の綠色ミの洎の境界は常に散漫であるがブルシナン、ブリニーでは鮮明であつた 白色ゴム(B)，此の簜合に於ける袙色及び色の回復は、或る點に於て、純ゴムに於て観测された ものに相異して居る。加硫したてのゴムは白色である、而して與へられたゴムの深さは一㞓早く着 色されるけれミ゙も色の回復は强度に就いてはより嗳漫なのである、ターンブルス、ブリユーはプル シフン、フリューより一居速かに其の色を回復する、而して八ヶ月後に前者は既に未加硫配合っ゙ム の有する淡青色になつて居る、然るにプルシナン、ブリューの䟠合物はなほ煺せだ綠青色であつた 純ゴムに於ては此の塲合と反對であつた。

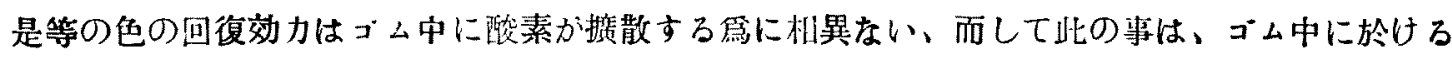
酸素の演散に就いての研究、老化作间の如き非唡に關聯する非常に重大な問題特に老化を促進する

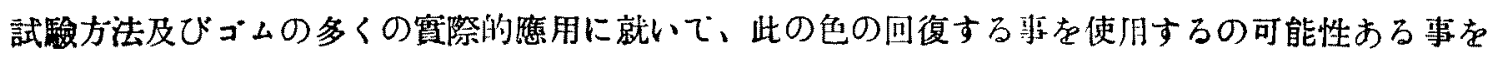
暗示して居る。

\section{第三章、フエロシアン化物が加硫コムの機械的性質に及ほす影響}

此の事は、95:5 のゴムと硫黄配合物（配合第 1 躆から第 6 號に至る、第一章参照）にて試駔さ れた、而して青色顔料も亦促進劑を加へた白色ゴ二（配合第13號から第15跟に至る、第二章 (b) 項 參照)にて試驗された。ブレスで加硫したゴムの性質が第四表に示されて居る；是等の數字はゴム 試料に就いて最適機悈的性質（耐伸强度、剛度及び恒久變形）及び最適加硫時問孝决定するに各配 合に就いて行つた加硫の範圍を示して居る。ブルシナン及びターンゾルス、ブリューを含有する配 合物は非常に速く酸化し損ずろので總てのゴムは試驗に供する迄型から出さずに置いた。 


\section{第 四表}

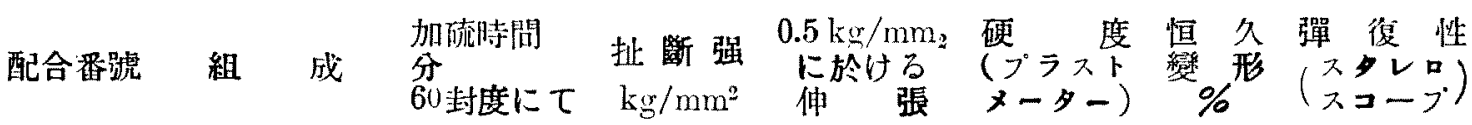

\begin{tabular}{|c|c|c|c|c|c|c|c|c|c|}
\hline 1. & 己合 & $\Lambda$ & & & 160 & 1.12 & 850 & 164 & 2.0 \\
\hline 2 . & $\theta$ & + & 12 & $\begin{array}{l}\text { ブルシ フン } \\
\text { ブทユー }\end{array}$ & 175 & 0.98 & 585 & 150 & 2.1 \\
\hline 3. & 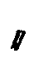 & $D$ & " & $\begin{array}{l}\text { ターンブルス } \\
\text { ブリュー }\end{array}$ & 220 & 0.63 & 645 & 156 & 2.9 \\
\hline 4. & "I & 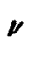 & $\|$ & $\underset{\text { 鉛 }}{\text { エロシアン }}$ & 210 & 0.78 & 830 & 172 & 2.5 \\
\hline 5. & II & $\|$ & $"$ & $\begin{array}{l}\text { フェロシフント } \\
\text { 亞领 }\end{array}$ & 215 & 0.92 & 750 & 158 & 1.8 \\
\hline 6. & $\nu$ & $\|$ & $\theta$ & ガスブラック & 150 & 1.31 & 485 & 129 & 2.4 \\
\hline
\end{tabular}

40 卦度にて

\begin{tabular}{|c|c|c|c|c|c|c|c|}
\hline 13. 配合 & & & 65 & 1.90 & 282 & 90 & 2.2 \\
\hline 14. $v+$ & +15 & $\begin{array}{l}\text { ブルシアン } \\
フ \text { フュフ }\end{array}$ & 125 & 0.99 & 384 & 130 & 3.9 \\
\hline 15." " & " I" & $\begin{array}{l}\text { ターンブルス } \\
\text { ブリュブ }\end{array}$ & 190 & 0.67 & 473 & 165 & 3.7 \\
\hline
\end{tabular}

配合 A. ت゙ム 95 硫黄 5

配合 B. ゴム 100 亞鉊華 100 チタニウムホワイト 30 硫黄 3.5 DPG 0.5

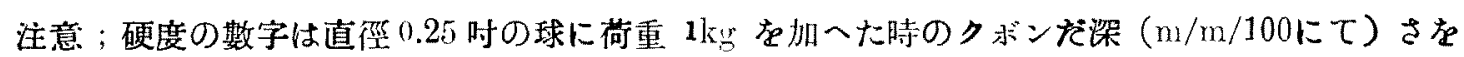
表はして后る。恒久變形は $400 \%$ (配合 1 から6まで) 或は $200 \%$ (配合13から15まで)に伸.張し て15分問放置して媵原形にもごし60分間經過後に测定せしものでおろ。

\section{（a）老化せぬコムの性 質}

總てのフェロシアン化物は加硫を掘らせ而伸强度を减ずる而して一般に恒久變形を垻加する；其の 二つのフリューの場合、是等の影響は特に白色ゴムに㤏て著しい。純ゴムに於てはフェロシアン化 物はゴムを强く通常硬くする、併し白色ゴムに於ては反對の影響を與へろのである；前者の塲合、

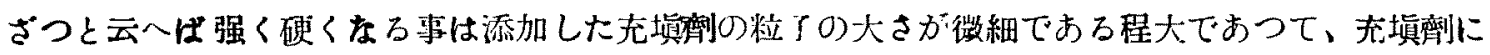
關する普通の見解通りである。彈復性は白色ゴムに於てのみ影製があり、二つのブリューは著しく 减退させてるる。それ故に一般にブルシアン及びターンプルス、ブリユーは促進劑を加へぬ( 純)ゴ ムに於けるより促進㓩を加へた（日色）ゴムに於て一居大なる有害な影響を及ぼすのでおつて、そ れは既にドーソンに依つて記截されてるろ事柄である。

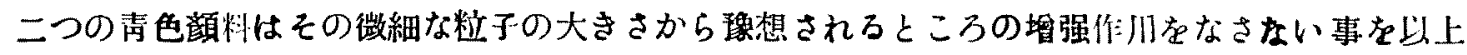


$\cdots(185) \cdots$

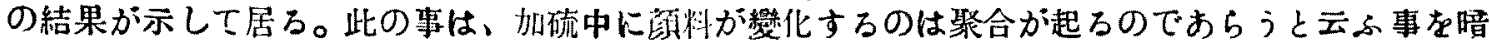

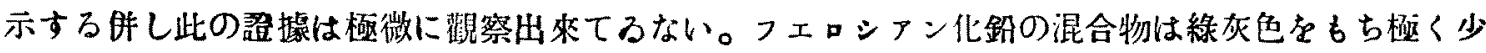
量硫化鉛に變化する事を示して居ろ。此のフェロシナン化鋗の安定度は多分、何故にに多くの鉛の 化合物が作蒯する如く）加硫を促進させないのであるか䛦朋出來る、何故なれてば樹脂酸はそれ存能 㗢的な鉛の監類に變扎する事が出來ないからである。 一一未完) 一

西田進譯 